\title{
MESTERSÉGES INTELLIGENCIA ÉS GÉPI LÁTÁS ESZKÖZÖK VIZSGÁLATA AZ IPAR 4.0 RENDSZERFEJLESZTÉSI KÖRNYEZETÉBEN
}

\author{
Balogh Bence \\ hallgató, Miskolci Egyetem \\ Logisztikai Intézet \\ 3515 Miskolc, Miskolc-Egyetemváros,e-mail:balogh.bence.cc@gmail.com
}

\begin{abstract}
Absztrakt:
Elérkeztünk a negyedik ipari forradalom (Ipar 4.0) kialakulásához, ami számos újdonságot, lehetöséget, problémát, elvárásokat és követelményeket hoz magával. Ahhoz, hogy minél sikeresebben alkalmazzuk az Ipar 4.0-t és képesek legyünk standardizálni, újszerü gondolatokra és kutatási tevékenységekre van szükség. Ez az új ipari forradalom nem csak a technikai újitásokról szól, hanem hogy a jelenleg rendelkezésre álló technológiákat képesek legyünk összekötni, ezekkel kapcsolatot teremtve az ipar és egyéb ágazatok között, illetve integrálni a logisztikába a legkorszerübb informatikai fejlesztéseket.
\end{abstract}

Kulcsszavak: Ipar 4.0, IOT, logisztika, ellátási lánc menedzsment

\begin{abstract}
:
We have come to the emergence of the Fourth Industrial Revolution (Industry 4.0), which brings many novelties, opportunities, problems, expectations and requirements. In order to be able to use Industry 4.0 more successfully and be able to standardize, new ideas and research activities are needed. This new industrial revolution is not only about technical innovations but also the ability to connect the technologies currently available, linking them to the industry and other sectors, and incorporating the most up-to-date IT developments into logistics.
\end{abstract}

Keywords: Industry 4.0, IOT, logistics, supply chain management

\section{Bevezetés}

Elérkeztünk a negyedik ipari forradalom (Ipar 4.0) kialakulásához, ami számos újdonságot, lehetőséget, problémát, elvárásokat és követelményeket hoz magával. Ahhoz, hogy minél sikeresebben alkalmazzuk az Ipar 4.0-t és képesek legyünk sztochasztikus rendszerekkel dolgozni, újszerü gondolatokra és kutatási tevékenységekre van szükség. Ez az új ipari forradalom nem csak a technikai újításokról szól, hanem hogy a jelenleg rendelkezésre álló technológiákat képesek legyünk összekötni, ezekkel kapcsolatot teremtve az ipar és egyéb ágazatok között [1].

Kutatómunkámat a Miskolci Egyetem Logisztikai Intézetében folyó, az Ipar 4.0 logisztikai területen történő alkalmazását célzó kutatásokra alapozva végeztem. Az intézeti kutatások nem csupán a kiberfizikai ellátási láncok különböző területeinek fejlesztési lehetőségeit taglalják [2-3], hanem az üzemen belüli, kiberfizikai gyártási környezet vizsgálatára is fókuszálnak [4-5]. 


\section{Mesterséges intelligencia}

Ahhoz, hogy jobban megértsem és átlássam az IoT müködését, egy saját projektet valósítottam meg otthoni automatizálás területen, ami örökíthető Smart Factory koncepcióvá is további bővítésekkel, fejlesztésekkel. Számomra az Amazon Lab126 által kifejlesztett „Alexa” Echo Dot v2 virtuális asszisztens szolgáltatta az alapot a fejlesztéshez, ami képes hang alapú interakciók kezelésére, szórakoztató funkciókra, mint zenelejátszás, tennivaló lista összeállítás, ébresztők/riasztások kezelése, podcastok/hangoskönyvek lejátszása, idöjárás, forgalom és egyéb valós idejü visszajelzések közlésére [6]. Azért esett erre a termékre a választásom, mert kutatásaim alapján az Amazon Alexa-nak van az egyik legmegbízhatóbb IoT háttere és felhőszolgáltatása. Az Echo készülékekben rendkívül minőségi a hangfelismerés, és itt a legjobban támogatottak az egyedi fejlesztési lehetőségek, akár otthoni automatizálási rendszer tekintetében is.

A projektemben a Belkin által gyártott WeMo készülékek müködési elvéhez hasonlóan készítek egy „okos” elosztót, ami egy mikrokontroller által vezérelt relé soron keresztül müködtethető hangvezérléssel az Echo Dot közelében, vagy telefonról bárhonnan, ahol internet áll rendelkezésre.

A WeMo eszközök UPnP-t (Universal Plug and Play - hálózati protokoll típus) - amelynek lényege, hogy bármilyen eszköz egyszerüen, bonyolult beállítások nélkül csatlakoztatható legyen egy hálózathoz - használnak bizonyos funkciók végrehajtásához a hálózaton keresztül [7]. Esetünkben az eszközészlelés Alexa segítségével történik, tehát WeMo-szerü eszközöket fog keresni UPnP használatával. Az eszköz válaszol Alexának a saját URL-jével (Uniform Resource Locator - egységes erőforrás-hely) HTTP (HyperText Transfer Protocol - információátviteli protokoll) protokollal UDP-n keresztül (User Datagram Protocol - az internet egyik alapprotokollja). A Dot ezután lekéri az eszköz leírását, majd HTTP válaszként jelenik meg. A WeMo eszközök tényleges be- és kikapcsolási funkciója egyszerübb, mivel itt az EchoDot már tud a készülékröl. Csatlakoznak egymáshoz HTTP felületen, és csak kiad egy „SetBinaryState” parancsot. Az eszközünk ezt követően kötelezi és visszaadja az igazolást HTTP -n keresztül az 1 . ábra szerint.

A projekt fizikai felépítése kerül a továbbiakban bemutatásra. Az alapot egy ESP8266-os Wifi képes mikrokontroller biztosítja, aminek a D1-D2-D3-D4 tüje a relésor elemeinek vezérlésére van kiosztva, illetve 3.3V tápot szolgáltat a müködéshez és GND földet. Az ESP8266 müködéséhez bármilyen $5 \mathrm{~V}$-os forrás megfelelő. Lehet ez számítógépről microUSB kábelen, hordozható akkumulátorról, telefontöltőrooll vagy hálózaton keresztül transzformátorral. Az elosztó egyik ága (2. ábra fehér) megmarad eredeti állapotában, a másik (2. ábra fekete) pedig megszakításra kerül és a relén kerül átvezetésre. Amikor a relé zárt állapotba kerül, az zárja az áramkört, és áram alá helyezi az elosztó bizonyos aljzatát.

Programozási szinten a korábban említett elv valósul meg. A program eleje, ahol behívásra kerülnek a használt könyvtárak és egyéb scriptek, illetve deklarálom a be/kikapcsolási funkciókat. Utána megadom a saját Wifi hálózatom nevét és jelszavát, majd alaphelyzetbe állítom a csatlakozás logikai változóját és a kapcsolók értékeit. A második szegmensen látható a kapcsolók definiálása az UPnP átvitelhez. Itt lehet megadni, hogy milyen azonosítóval szeretnénk majd vezérelni az egyes relék állapotát, milyen porton folytatjuk le a kommunikációt, és mi a be- és kikapcsolás hívójelzése, amiket a hangutasításhoz használunk majd. Ezalatt definiáljuk a pin kiosztást a mikrokontrolleren, hogy melyikeken keresztül fogjuk küldeni a vezérlő jeleket. Ez esetünkben a 5-4-0-2, ami megfelel az ESP8266 D1-D2-D3-D4 jelzéseinek. A harmadik szegmens pedig betekintést nyújt az egyes funkciókba, hogy milyen üzenetet küld az egyes utasításokra, és hogyan állítja a relék állapotát aktívról passzívra. 


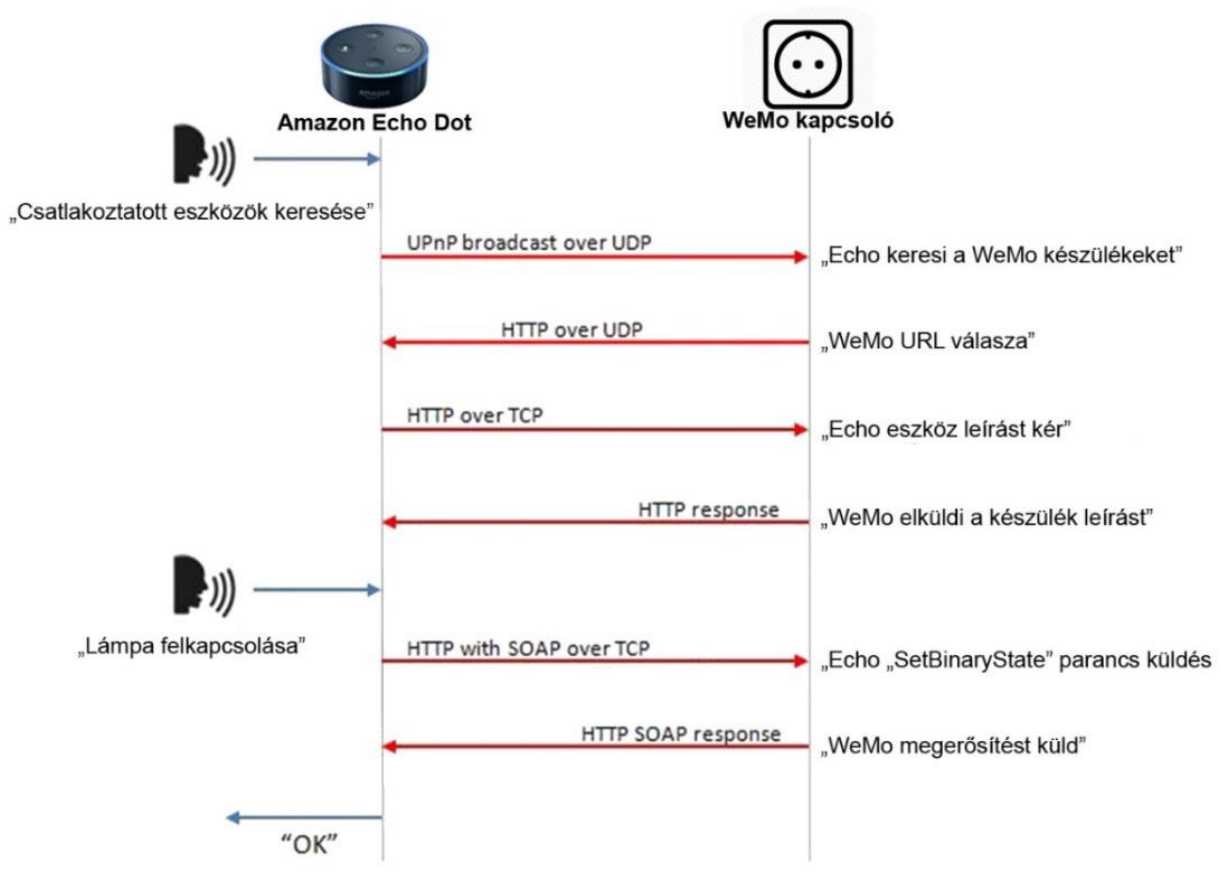

1. ábra. UPnP kommunikáció ${ }^{1}$

Így sikerült létrehozni egy olyan „okos” elosztót, amiben a csatlakoztatott eszközöket hanggal lehet ki- és bekapcsolni, vagy telefonról. A hangutasítások is teljesen személyre vagy eszközre szabhatók, de jelen esetben az egyszerüség kedvéért a négy aljzat most „Light1-2-3-4” vezérszavakra reagál. Tehát ha azt mondjuk az Echo Dot jelenlétében, hogy: „Alexa, switch on light one”, a kommunikáció és azonosítás megtörténik, majd az egyes számú relé kapcsol zárva az áramkört és az elosztó első aljzatában lévő villanykörte felkapcsol. Ha azt mondjuk, hogy: „Alexa, turn off light one”, akkor lekapcsol az eszközünk. Az Amazon szerverei jelenleg csak angol nyelvü hangfelismerést tesznek lehetővé, de amint látható, taníttatással a szavak szinonimái se zavarják meg a müködésben, továbbá csoportok is létrehozhatók. Például, ha az otthoni automatizálásnál maradunk, akkor a „Turn on/off bedroom" egyszerre vezérelheti a projektünkben létrehozott négy relét, mert lehet, hogy be- és kikapcsolásuk egyszerre szükséges.

Konklúzióként beismerhetjük, hogy már otthoni felhasználás mellett is számtalan lehetőség rejlik egy IoT platformban, amit ha kombinálunk egy AI (artificial intelligence) rendszerrel és szenzorokkal, relékkel, akkor egy okos otthon automatizált feladatokkal könnyedén létrehozható. Amennyiben nagyobban gondolkodunk, ez a tudás és eszközpark átültethető a Smart Factory gyárakba, ahol a korábbi fejezetekben említett automatizált, autonóm, önszervező gyártás kialakítható. Egy logisztikai üzemben egyszerüen lekérhetővé válnak az információk akár hangutasítással, gépek és folyamatok vezérelhetők távolról.

\footnotetext{
${ }^{1}$ http://www.instructables.com/id/When-IoT-Meets-AI-Home-Automation-With-Alexa-and-N/
} 


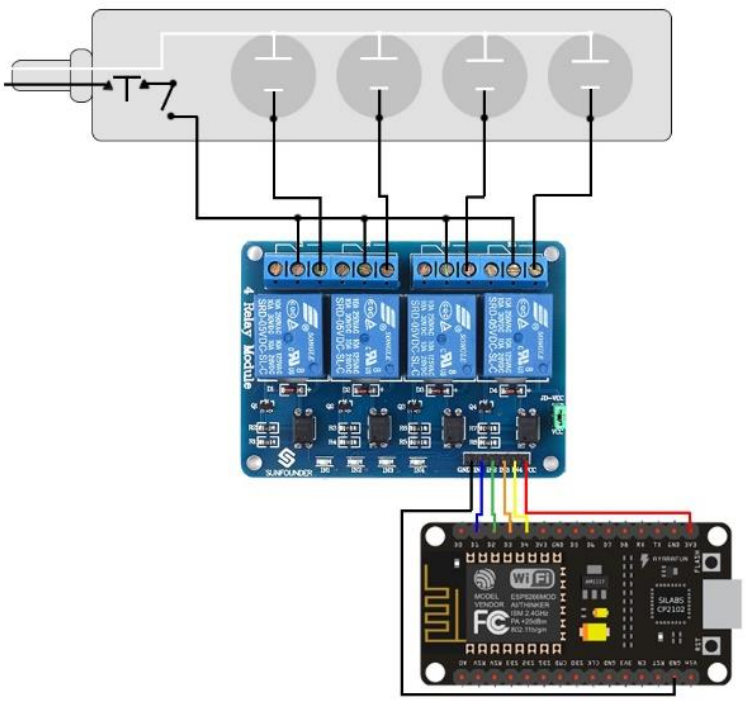

2. ábra. Okos elosztó

\section{Gépi látás}

A korábbiakban tárgyalt VR, $\mathrm{AR}, \mathrm{AI}$, IoT eszközök mind a mai trendeknek megfelelő jövőbemutató technológiák. Azonban, hogy kapcsolatot teremtsünk a gépek és a világ között, nem elég egy virtuális teret alkotni, fel kell ismerni a valós elemeket, hogy minél egyszerübb legyen az átjárás és a kommunikáció, gép és ember számára.

„A gépi látás fogalma tágabb a robotlátás fogalmánál. Legáltalánosabban a gépi látás a gép által a környezetéröl, vagy a müködése által érintett objektumokról készitett kép számitógépes elemzését jelenti abból a célból, hogy a gép a készitett képböl az általa végzett müködésben hasznositható információt nyerjen ki. A látvány fényképezö eszközzel, kamerával, vagy egyéb speciális szenzorral való elkészitése és a képállomány memóriában való letárolása után az érdemi folyamat a digitális képfeldolgozás témakörébe tartozik." [8].

Korábbi TDK dolgozatomban már sikerült egy egyszerü gépi látás alapú AR programot létrehozni, ahol a Miskolci Egyetem logóját felismerve a gép egy „TDK2017” virtuális alakzatot helyezett az A4es papírlapra. Ezen a szálon tovább haladva, a következő kihívás az volt, hogy egy olyan programot alkossak meg, ami a „marker” (speciálisan meghatározott objektum) felismerésére valamilyen feladatot hajt végre. Ehhez a projekthez is a Unity programot használtam, ami egy ,videojáték-motor, amelyet a Unity Technologies fejleszt. A Unity segítségével háromdimenziós illetve kettődimenziós videojátékokat, ezen kívül egyéb interaktív jellegü tartalmakat lehet létrehozni, például építészeti látványterveket vagy valós idejü háromdimenziós animációkat. Többek között elönye, hogy a szoftver képes nagyméretű adatbázisokat kezelni, kihasználni a kölcsönhatások és animációk képességeit, előre kiszámított vagy valós idejü világítást biztosítani. Továbbá használható geometriai eszközcsomagok továbbítására, illetve viselkedési elemek hozzáadására egyes objektumokhoz. Ezek mellett a játékmotor folyamatosan megőrzi a végleges változat megjelenítését." [9] 
A hardveres koncepció egy Arduino Uno fejlesztő lap, amihez egy relé van kapcsolva, ahogy a 3. ábra is szemlélteti. A Unity végzi a marker felismerési feladatot „Ray casting” elven, tehát egy pontszerủ kiterjedéssel rendelkező sugarat vetít a kamera irányából, és azt vizsgálja, hogy ez a sugár mikor metsz egy általunk megalkotott objektumot. Amennyiben ez bekövetkezik, akkor jelet küld soros porton az Arduino számára, ami 1 vagy 0 . A 4. ábrán látható az Arduino kód, ami folyamatosan adatot olvas, és ha 1-est kap, akkor a 8-as számú vezérelt pin állapotát aktívra állítja, ami kapcsolja a relét, ami aktiválja az eszközünket. Ha megszünik a sugár és az objektum metszése, akkor 0-t fog küldeni a Unity az Arduino-nak, ami ennek hatására megszüntetni a jelet a vezérlő pin-en és ezzel lekapcsolja a relét, megszüntetve az eszközünk müködését.

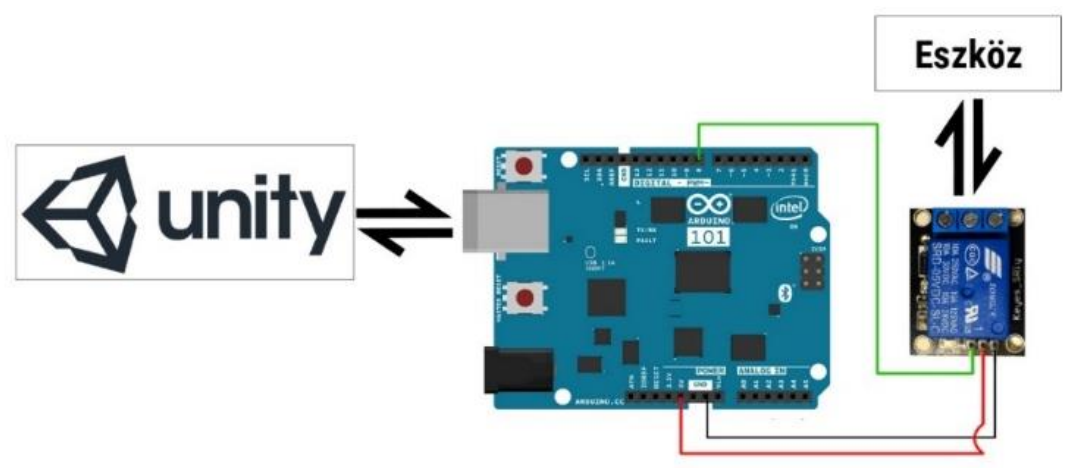

\section{3. ábra. Hardver koncepció}

Kipróbálásra került egy másik pásztázási módszer is, a „Sphere cast”, ami közel azonos a Ray casttal, csak egy gömbre végződik a vizsgáló sugár, és amint érintkezik egy objektummal, akkor teljesül a feltétel. Ez a módszer túlzott szenzitivitással járt és kisebb mozdulatok is befolyásolták a müködést. Ha pedig kellően kicsire lett véve a gömb, akkor pedig elveszítjük a gömb által lefedett területet, így pedig az eredmény szinte ugyanaz, mint a sugár esetében.

A következő problémát az jelentette, hogy az objektum csak addig volt aktív, amíg ütközött a sugárral, ez viszont nem nyújtott valós felhasználási élményt. Hiszen gondoljunk csak bele, ha ez egy egyszerü lámpa felkapcsolását szolgálná, akkor a lámpa csak addig maradna felkapcsolva, amíg folyamatosan arra nézünk. Olyan módszerre volt szükség, ami képes tárolni az állapotot. Ezért bevezetésre került egy logikai bool változó a Unity C\# kódban, amit alapesetben hamisra állítunk, és vizsgálatot végzünk a változóra, amikor aktív lesz a feltétel. Ha a logikai változó hamis, akkor az objektumunkat még nem találtuk meg korábban, tehát indulhat a folyamat, és ebben a pillanatban igazra állítjuk a bool változót. Így az újabb vizsgálatnál ebbe a feltételrendszerbe már nem tudunk belépni, csak a másik, kikapcsoló ágba, amiben a logikai változót visszaállítjuk hamisra, tehát szabad az objektumunk, a relénk kikapcsolt állapotban van.

Tehát ilyen állapotban egy fix képet, markert fel lehet ismerni egy külső vagy beépített kamera segítségével és soros kommunikációval a mikrokontrolleren keresztül vezérelhetünk különböző eszközöket. Folytatva a gondolatmenetet: logisztikai környezetben a komissiózásnál a leltározás megkönnyíthető, ha a QR kódokat vagy vonalkódokat egy hasonló rendszerrel lehetne feldolgozni. 


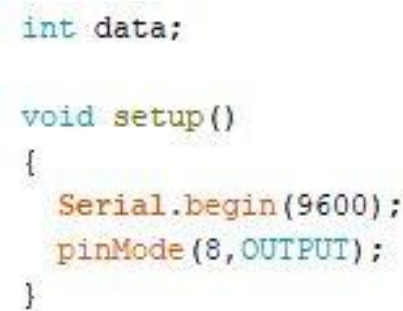

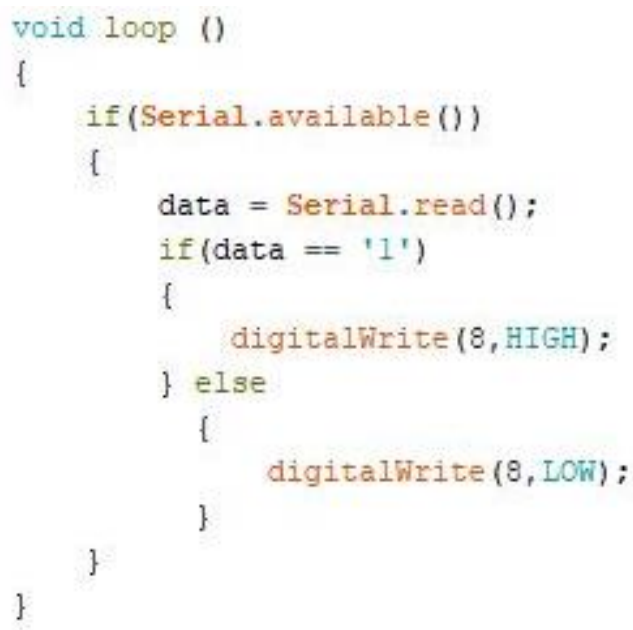

\section{4. ábra. Arduino kód}

Ugyanis ebben az esetben nem kellene manuálisan bevinni, átellenőrizni az anyagmozgást, hanem egy hálózatba kötve a beolvasás után automatikusan megoldódna. A korábbi programot úgy lehet mobilissá alakítani, ha valami hordozható eszközre fordítjuk le. Egy Android rendszert futtató telefonra sikerült megvalósítani egy QR kód és vonalkód olvasó alkalmazást, ami felismeri az adathalmazt, majd megjeleníti a tartalmát. Ehhez szükség van egy olyan adatbázisra, amivel tud kommunikálni, és így egy IoT rendszer alakítható ki.

Tovább haladva egy újabb lehetőséget sikerült felfedezni: a mesterséges neurális hálókat. Ennek a módszernek a célja, hogy elősegítse a gépi tanulást. Az emberi agy szimulálása nagy kihívás, és rengeteg innovatív lehetóséget hordoz magában. Így a számítógép rendszeres taníttatás mellett képes lesz önállóan felismerni, illetve megkülönböztetni dolgokat. Így elhanyagolhatóvá válnának a hagyományos értelemben vett képfelismerések és markerek alkalmazása, hiszen a gép ezektől függetlenül ismerné fel az általunk választott alakzatokat. Egy logisztikai komissiózó üzemben ez nagyban felgyorsítaná a válogatás folyamatát és jelentősen csökkentené a hibalehetőségeket. Hiszen a gép magától el tudná dönteni, hogy mi a különbség például egy csavar és egy alátét között.

ArUco és TensorFlow programok segítségével, több heti taníttatás után sikerült egy fali kapcsoló alakzatot megtanítani a számítógépnek. Ezt implementáltuk Unity-be és kombináltuk a korábbi tapasztalatainkkal. A hardveres felépítés továbbra is egy mikrokontrollert tartalmaz, ami elosztóba integrált reléket irányít. Ha a kamerát egy kapcsoló vagy kapcsolóról készült kép felé irányítjuk, akkor kis idő elteltével felismeri azt, amit úgy jelez, hogy egy digitális alakzattal fedi le. Innentöl kezdve pedig a korábban bemutatott módszer alapján, ha sugár találkozik az objektumunkkal, akkor kapcsoljuk a relét, és erről olyan vizuális visszajelzést kapunk, hogy a virtuális alakzatunk pirosra színeződik. A megjelenítő felület arról is tájékoztat minket, hogy milyen távolságban helyezkedik el a fali kapcsoló, illetve szövegesen is megjeleníti, hogy be- vagy kikapcsolt állapotban van-e az eszközünk. 


\section{4. Összefoglalás - Jövőbeli kutatási irányok}

A neurális háló fejlesztésével és folyamatos tanításával új kapuk nyílnak meg a tudományban és az iparban. Fejlesztési szempontból a hordozhatóságon és az IoT-n van a hangsúly. Megoldást kell találni, hogy ne csak soros porton történhessen a kommunikáció, hanem interneten keresztül. Ehhez jobban meg kell ismerni a Wifi-képes mikrokontrollereket, és felfedezni a legegyszerübb és leggyorsabb módját a Unity és Arduino közötti adattovábbításra. Érdemes lehet a web szerverek és a közvetlen internetcsatlakozási módszerek vizsgálata, illetve az Amazon Echo Dot projektből megismert UPnP protokoll további elemzése.

Miután elérhetővé válik a vezeték nélküli kapcsolat, a kompakt hordozhatóság is könnyebben kutatható. A megszerzett ismereteket át lehet ültetni mobiltelefonos applikációkba, amelyek széles körben elterjedtek és bárki számára elérhetőek. Viszont ebben az esetben számolni kell a hardveres különbözőséggel, ami gondot okozhat. Kifinomultabb platformok az „okos szemüvegek”, mint a Epson Moverio Smart Glass, a Google Glass és a Microsoft HoloLens. Az ilyen komolyabb vagy optimalizált hardverrel rendelkezö eszközök jobban alkalmazhatók ilyen feladatokra, hiszen céleszközök. Képesek a kiterjesztett valóság alapú kezelöfelület kivetítésére és nem akadályozzák a kezünk használatát.

További felhasználási területeket is érdemes figyelembe venni. A neurális hálózattal egy épület jellemző elemeinek megtanítása segíthet belső tájékozódásban szállításnál vagy látássérült embereknek, mert a cikkírásának ideje alatt is a különböző objektumok távolságának meghatározása (bizonyos határokon belül) és a megnevezésük gépi bemondása lehetséges.

\section{Köszönetnyilvánítás}

Ezúton szeretnék köszönetet mondani témavezetőmnek Prof. Dr. habil. Illés Bélának, aki szakértelmével és tanácsaival nagyban segítette munkámat. Köszönet illeti Dobos Gergelyt, aki szakmai tapasztalatával és hasznos tanácsaival segítette a mesterséges intelligencia és neurális háló projektek létrejöttét. Köszönöm a Bay Zoltán Alkalmazott Kutatási Közhasznú Nonprofit Kft.-nek a szakmai támogatást és az eszközhasználat biztosítását.

„A cikkben ismertetett kutató munka az EFOP-3.6.1-16-2016-00011 jelű „Fiatalodó és Megújuló Egyetem - Innovatív Tudásváros - a Miskolci Egyetem intelligens szakosodást szolgáló intézményi fejlesztése" projekt részeként - a Széchenyi 2020 keretében - az Európai Unió támogatásával, az Európai Szociális Alap társfinanszírozásával valósul meg".

\section{Irodalom}

[1] Illés B. \& Tamás P., (2016). Gyártórendszerek folyamatfejlesztési lehetöségei a negyedik ipari forradalomban/Process improvement possibilities for manufacturing systems in the industry 4.0. Müszaki Szemle, 18(67), 41-48. https://doi.org/10.1088/1757-899X/161/1/012074

[2] Bányai T., Tamás P., Illés B., Živilè S. \& Bányai Á. (2019) Optimization of Municipal Waste Collection Routing: Impact of Industry 4.0 Technologies on Environmental Awareness and Sustainability. International Journal of Environmental Research and Public Health 16(4): 1-26. https://doi.org/10.3390/ijerph16040634 
[3] Ehrentraut F., Landschützer C., Telek P. \& Bányai T. (2018) A new network concept for Logistic Centres in Hungary - regional segmentation in line with the PI vision. In: Proceedings of the 5th International Physical Internet Conference Groningen, Hollandia : University of Groningen, pp.129-141.

[4] Kota, L. (2018) Mesterséges intelligencia a logisztikában: Alkalmazások és algoritmusok. Gépgyártás 52(1-2): 33-39.

[5] Poenicke O., Kirch M., Richter K., Schmid F. \& Telek P. (2017) Wearable solutions for efficient manual logistics processes - RFID Wristband and Smart-Glasses. In: Christian, Landschützer; FlorianEhrentraut (szerk.) 4th International Physical Internet Conference Graz, Ausztria : Institut für Technische Logistik, pp.160-169.

[6] Amazon Alexa: https://developer.amazon.com/docs/alexa-voice-service/api-overview.html

[7] When IoT meets AI: Home automation with Alexa and NodeMCU (2017) http://www.instructables.com/id/When-IoT-Meets-AI-Home-Automation-With-Alexa-and-N/

[8] Dudás L. (2011): Alkalmazott Mesterséges Intelligencia. https://www.tankonyvtar.hu

[9] Unity 3D: https://unity3d.com/unity/whats-new/unity-2017.3.1 